\title{
ANTIBACTERIAL, ANTIDIABETIC AND BRINE SHRIMP LETHALITY ACTIVITIES OF SOME SELECTED MEDICINAL PLANTS FROM KAVREPALANCHOK DISTRICT OF NEPAL
}

\author{
Khaga Raj Sharma*, Rupak Kharel \\ Central Department of Chemistry, Tribhuvan University, Kirtipur, Kathmandu, Nepal \\ *Corresponding author: khagaraj_sharma33@yahoo.com
}

(Received: January 31, 2019; Revised: April 4, 2019; Accepted: April 12, 2019)

\begin{abstract}
The methanol extracts of nine medicinal plants collected from Kavrepalanchok district of Nepal were subjected to their potential bioactivity viz. antibacterial, antidiabetic and toxicity tests. Antibacterial property of the extracts was evaluated against Gram-positive and Gram-negative bacteria by agar well diffusion method and antidiabetic activity was investigated by $\alpha$-amylase inhibition assay. The toxicity of plant extracts was assessed by brine shrimp lethality test. All the nine different plant extracts showed antibacterial activity with the zone of inhibition (ZOI) ranging from 5 to $35 \mathrm{~mm}$. Among the studied plant extracts, Psidium guajava showed the highest ZOI against Salmonella typhi (35 mm) while Melia azedarach was most effective against Staphylococcus aureus $(22 \mathrm{~mm})$. The percentage of $\alpha$ - amylase enzyme inhibition was found up to $88.56 \pm 3.50$ in dose dependent manner. The enzyme inhibitory concentration $\mathrm{IC}_{50}$ value of standard, acarbose was $166.01 \mu \mathrm{g} / \mathrm{mL}$ while the most effective anti-diabetic plant extract of Utrica dioica has 186.67 $\mu \mathrm{g} / \mathrm{mL}$. Moreover, various plant extracts depicted various levels of toxic activities; Curcuma longa demonstrated significant toxicity to Artemia salina with $\mathrm{LC}_{50}$ value $62.10 \mu \mathrm{g} / \mathrm{mL}$, while Agerantina adenophora, P. guajava and M. azedarach showed moderate toxicity with $103.77,109.37$ and $383.58 \mu \mathrm{g} / \mathrm{mL}$, respectively.
\end{abstract}

Keywords: Medicinal plants, Antidiabetic, Toxicity, Antibacterial, ZOI

\section{INTRODUCTION}

A great biodiversity owing to varied geographical, geomorphological and climatic condition of Nepal has provided it many plants with medicinal and aromatic values (Baral 2005). Kavrepalanchok districts of Nepal lies between latitude $27^{\circ} 21^{\prime}-27^{\circ} 42^{\prime} \mathrm{N}$ and longitude $85^{\circ}$ $23^{\prime}-85^{\circ} 49^{\prime} \mathrm{E}$. The altitude vary from $200-3018 \mathrm{~m}$, and the average temperature ranges from 10 to $31^{\circ} \mathrm{C}$ (Chhetri \& Gauchan 2007). About $80 \%$ people living in rural areas of underdeveloped countries still depend on medicinal plants for their primary health care (Muhammad et al. 2011). Studies revealed that there was more traditional medicine provider than the allopathic practitioners especially in the rural areas (WHO 2002). In Kavrepalanchok, many communities dwell in rural areas and have no access to modern medicine. Therefore, large proportions of population especially of ethnic communities depend upon the medicinal plants to cure minor malady.

Antibacterial is an agent that kills or inhibits bacteria by directly killing them or interfere the reproduction process, thereby inhibiting bacteria proliferation. After the introduction of first antibiotic penicillin, pathogenic bacteria causing infectious diseases have been contained. However, reckless and irregular administration of commercial antibacterial drugs resulted in bacteria to develop drugs, bacteria has developed resistance against the drugs, necessitating the scientists to explore new and effective antibacterial agents that can be better alternative of current regimens (Roa et al. 2018, Manik et al. 2013). Therefore, the drug development from natural product is promising as plants show different bioactivity to cure ailments due to the presence of bioactive compounds (Joshi \& Bashyal 2018, Giri \& Rajbhandari 2018, Sharma et al. 2015a, 2015b).

Diabetes mellitus is a metabolic disease characterized by high blood sugar (glucose) levels resulting from defects in insulin secretion, or its action, or both. Such deficiency results in increased concentration of glucose in the blood which in turn damages the body's system particularly in blood vessels and nerves. Numerous medicines have been developed in order to check diabetes; however, continuous use decreases their efficacy and shows some side effects. Inhibition of $\alpha$-amylase therapy is responsible for delaying the absorption of glucose after meal. Several $\alpha$-amylase inhibitors have been isolated from medicinal plants for the development of new drugs with increased potentiality and lower side effects than the existing one (Arif et al. 2014). Plants are a potent source of antidiabetic agents. Many synthetic drugs have been synthesized to cure the diabetic mellitus. However, they are expensive and have numerous side effects. Several studies have shown that some plants used in traditional medicine have beneficial effects in diabetic patients. More than 400 plants worldwide have been documented as beneficial in the treatment of diabetes (Sathiavelu et al. 2013). 
Toxicity studies are useful initial step in determining the potential toxicity of a substance, including plant extracts or biologically active compounds isolated from plants. Minimal to no toxicity is essential for a successful development of pharmaceutical or cosmetic preparation and in this regard, cellular toxicity studies play a crucial role (Lyndy \& Jacobus 2014). For the bioactive compound of either natural or synthetic origin, lethality test is a rapid and comprehensive test. It easily utilizes a large number of organisms for statistical validation and requires no special equipment and relatively small amount of sample (2-20 mg or less) is sufficient (Sarah et al. 2017). The larva, nauplii about $22 \mathrm{~mm}$ long, are large enough to observe without high magnification and small enough for hatching in enormous amount without extensive workspace in a laboratory (Meyer et al. 1982).

\section{MATERIALS AND METHODS}

\section{Collection and identification of plant samples}

Different parts of nine medicinal plants Spondias pinnata, Melia azedarach, Psidium guajava, Agerantina adenophora, Utrica dioica, Bauhinia variegata, Achyranthes aspera, Curcuma longa and Eleocarpus anjastifolius were collected from a farmland of Panchkhal municipality, Kavrepalanchok, Nepal. The plants were collected in the summer (May/June) of 2017. The plants were identified by the Prof. Dr. Mohan Sivakoti and Prof. Dr. Sangeeta Rajbhandari, Central Department of Botany, Tribhuvan University, Kathmandu, Nepal.

\section{Extract preparation}

Cleaned parts of plants were dried under the shade at room temperature. Dried samples were chopped into pieces and powdered using a mechanical grinder. Dried powder $(100 \mathrm{~g})$ was mixed separately in $400 \mathrm{~mL}$ methanol. The flasks were sealed tightly and extraction was done for 72 hours with occasional shaking. The obtained extracts were filtered and concentrated in a rotary evaporator. The yield of each fraction was determined and all the extracts were stored at $4{ }^{\circ} \mathrm{C}$ in a refrigerator until analyses.

\section{Antibacterial assay}

Antibacterial screening of the plant extracts was performed by agar well diffusion method. Effectiveness of antimicrobial substance was evaluated by determination of ZOI as per the protocol adopted by Cavalieri et al. (2005) with little modification. The bacterial strains which were used for the test were obtained from Micro Med, Thapathali, Kathmandu.

The bacterial strains were Staphylococcus aureus (ATCC 25923), Escherichia coli (ATCC 25922) and Salmonella typhi. They were inoculated and cultured on nutrient broth. Sterile culture plates of Muller-Hinton agar were prepared. A McFarland 0.5 standard was prepared and the bacterial suspension was compared with it to adjust the turbidity of the inoculums for the susceptibility test. The inoculums of bacteria were transferred into Muller-Hinton agar using sterile cotton swab. The swab was used to spread the bacteria on the media in a confluent lawn. Wells were prepared by punching the bacterial culture inoculated agar plate with the help of sterile cork borer of $6 \mathrm{~mm}$ size. Four to six wells were made at equidistance on the plate. Then, 100 and $10 \mathrm{mg} / \mathrm{mL}$ of the working solution of the plant extract, $50 \%$ DMSO in water as a negative control and ofloxacin $(0.3 \%)$ as a positive control were loaded into the respective wells with the help of a micropipette. The plates were then left for half an hour with the lid closed so that the extract diffused into media. The plates were incubated overnight at $37^{\circ} \mathrm{C}$. After 24 hours of incubation, the plates were observed for the presence of inhibition of bacterial growth indicated by clear zone around the wells. The size of the ZOI was measured. The absence of ZOI was interpreted as the absence of activity.

\section{$\alpha$-Amylase inhibition assay}

$\alpha$-amylase inhibition assay was performed following the standard protocol (Kusano et al. 2011). Starch was used as a substrate; $\alpha$-amylase converts starch into sugars. But acarbose inhibits the action of $\alpha$-amylase and hence decreases or stops the conversion of starch. The plant extracts whose antidiabetic activities are to be examined, must have same property as acarbose, i.e. they should retard or inhibit activity of the $\alpha$-amylase enzyme. Acarbose, a drug used for treatment of type II diabetes mellitus was used as standard since it inhibits $\alpha$-amylase enzyme.

The amount of $40 \mu \mathrm{L}$ of starch solution was pre-incubated at $37^{\circ} \mathrm{C}$ for 3 minutes with $20 \mu \mathrm{L}$ of acarbose or plant extract at varying concentration of plant extract 40,80 , 160,320 and $640 \mu \mathrm{g} / \mathrm{mL}$ followed by adding $20 \mu \mathrm{L}$ of 3 $\mathrm{U} / \mathrm{mL} \alpha$-amylase which were dissolved in phosphate buffer solution and incubation at $37^{\circ} \mathrm{C}$ for 15 minutes. Termination of the reaction was carried out by adding 80 $\mu \mathrm{L}$ of $\mathrm{HCl}(0.1 \mathrm{M})$ in pre-incubated mixture having amylase. Then, $100 \mu \mathrm{L}$ of iodine reagent $(2.5 \mathrm{mM})$ was added in each solution and the final volume was made to 5 $\mathrm{mL}$ by adding distilled water. Absorbance was measured at $630 \mathrm{~nm}$. The assay was carried out in triplicate for reliable result. Percentage of inhibition was calculated using equation (1).

$\%$ inhibition $=(1-($ Abs2 - Abs $1 /($ Abs4 - Abs 3$) * 100$

Where,

Abs1 = absorbance of the incubated mixture containing plant sample, starch, and $\alpha$-amylase

Abs2 $=$ absorbance of incubated mixture of sample and starch 
Abs $3=$ absorbance of the incubated mixture of starch and $\alpha$-amylase

Abs4 = absorbance of incubated solution containing starch.

\section{Brine shrimp toxicity bioassay}

The toxicity assay was performed by using brine shrimp assay following the standard protocol (Meyer et al. 1982). The artificial sea water was prepared by dissolving $15 \mathrm{mg}$ of sodium chloride, $0.45 \mathrm{~g}$ of potassium chloride, $0.55 \mathrm{~g}$ of calcium chloride and $1.76 \mathrm{~g}$ of magnesium sulphate in distilled water to make $500 \mathrm{~mL}$ solution. Brine shrimp nauplii hatching tank was filled with water and the eggs sprinkled in to the covered part of the tank. The bioactive compounds/extracts show toxicity towards brine shrimp larvae. This method evaluates the toxicity of extracts towards the nauplii by determining the $\mathrm{LC}_{50}(\mu \mathrm{g} / \mathrm{mL})$. Compounds of $\mathrm{LC}_{50}$ value less than $1000 \mathrm{ppm}$ are considered as potentially pharmaceutically active. $\mathrm{LC}_{50}$ value is the total lethal concentration dose required to kill $50 \%$ of the shrimps. It can be determined as follows:

$\propto=\frac{1}{n}\left(\sum y-\beta \sum x\right)$

and

$\beta=\frac{\sum x y-\sum x \sum y / n}{\sum x^{2}-\left(\sum x\right)^{2} / n}$

where, ' $n$ ' is the number of replicates (here three), ' $x$ ' is the $\log$ of constituents in $\mathrm{mg} / \mathrm{mL}(\log 10, \log 100$ and $\log 1000$ for three dose level respectively, ' $y$ ' is prohibit for average survivor of all replicates.

From probit regression $y=\alpha+\beta x$

$X=\frac{(y-\alpha)}{\beta}$

where, $\mathrm{Y}$ is a constant having value 5 for calculating $\mathrm{LC}_{50}$ values.

Thus, $\mathrm{LC}_{50}=$ Antilog $\mathrm{X}$

\section{Statistical analysis}

Data were recorded as mean \pm standard deviation of three determinations of absorbance for each concentration from which linear correlation coefficient $\left(R^{2}\right)$ value was calculated using MS Office Excel 2007. The linear regression equation for a straight line is, $\mathrm{y}=\mathrm{mx}+\mathrm{c}$ where, $\mathrm{y}=$ absorbance of the extract, $\mathrm{m}=$ slope of the calibration curve, $\mathrm{x}=$ concentration of the plant extract and $\mathrm{c}=$ intercept.

\section{RESULTS AND DISCUSSION}

Quantitative estimation of extract and percentage yield of nine different plants was studied on the methanol solvent. Different plants gave different percentage of yield. The yield percentage recovery of extract ranged from 2.94 percent to 19.38 percent in Utrica dioica and Bauhinia variegate, respectively. Table 1 presents the percentage yield of different plant extracts. The yield percentage was found in varied quantities and it might be due to the solvent polarity which affects the solubility of the constituents found in different plant parts.

\section{Table 1. Percentage yield of different plant extracts}

\begin{tabular}{lrll}
\hline Name of plants & $\begin{array}{l}\text { Quantity } \\
\text { (g) }\end{array}$ & Part used & $\begin{array}{l}\text { Percentage } \\
\text { yield (\%) }\end{array}$ \\
\hline S. spinnata & 100 & Bark & 13.79 \\
M. azedarach & 100 & Bark & 13.79 \\
P. guajava & 100 & Bark & 15.63 \\
\hline A. adenophora & 100 & Whole plant & 10.33 \\
U. dioica & 100 & Root & 2.94 \\
B. variegate & 100 & Bark & 19.38 \\
A. aspera & 100 & Whole plant & 5.61 \\
\hline C. longa & 100 & Rhizome & 9.67 \\
\hline E. anjastifolius & 100 & Seed & 5.62 \\
\hline
\end{tabular}

\section{Antimicrobial activity}

Antibacterial activity of the extract of different plants evaluated in vitro against Gram-positive and negative bacteria is shown in Table 2. The measurement of ZOI produced by different plant extracts at concentration of 10 $\mathrm{mg} / \mathrm{mL}$ and $100 \mathrm{mg} / \mathrm{mL}$ against three different bacteria Salmonella typhi, Escherichia coli and Staphylococcus aureus are illustrated in Table 2. All the extracts exhibited some antibacterial activity against potential pathogenic bacteria. Previous study showed that high antibacterial activity was recorded in $P$. guajava extract with ZOI 35 $\mathrm{mm}$ and in $A$. aspera extract with $19 \mathrm{~mm}$ of clear inhibition zone against $S$. typhi and $E$. coli respectively. Methanolic extract of P. guajava showed mean ZOI 8.27 and $12.3 \mathrm{~mm}$ against Bacillus cereus and $S$. aureus, respectively and no ZOI against Gram-negative bacteria (Biswas et al. 2012). The zone of inhibition increased with increase in the concentration of plant extracts (Pokhrel et al. 2015). Standard antibiotic, ofloxacin (0.3 $\%$ ) showed zone of inhibition ranging from 20 to $38 \mathrm{~mm}$ against all test organisms. The antibacterial activity showed by different plant extracts can be attributed to different secondary metabolites present in plants.

ZOI ranged from $12 \mathrm{~mm}$ to $19 \mathrm{~mm}$ against $E$. coli and 19 $\mathrm{mm}$ being ZOI of $P$. guajava at $100 \mathrm{mg} / \mathrm{mL}$ concentration and the standard, ofloxacin $(0.3 \%)$ showed ZOI of 35 $\mathrm{mm}$. Similarly ZOI ranged from $12 \mathrm{~mm}$ to $22 \mathrm{~mm}$ against $S$. aureus. $22 \mathrm{~mm}$ being of $M$. azederach at $100 \mathrm{mg} / \mathrm{mL}$ concentration and the standard, ofloxacin $(0.3 \%)$ showed ZOI of $38 \mathrm{~mm}$ against $S$. typhi. The plant extract of 
Psidium guajava showed ZOI $35 \mathrm{~mm}$ was the remarkable antibacterial potential against Salmonella typhi at 100 $\mathrm{mg} / \mathrm{mL}$ concentration. The standard, however, showed ZOI of only $20 \mathrm{~mm}$ against $S$. typhi strain.

Table 2. Antibacterial activity of plant extracts on Salmonella typhi, Escherichia coli and Staphylococus aureus

\begin{tabular}{|c|c|c|c|c|c|c|}
\hline \multirow[t]{2}{*}{ Plant extracts } & \multicolumn{2}{|c|}{$\begin{array}{l}\text { ZOI mm } \\
\text { (Salmonella typhi) }\end{array}$} & \multicolumn{2}{|c|}{$\begin{array}{l}\text { ZOI mm } \\
\text { (Escherichia coli) }\end{array}$} & \multicolumn{2}{|c|}{$\begin{array}{l}\text { ZOI mm } \\
\text { (Staphylococcus aureus) }\end{array}$} \\
\hline & $10 \mathrm{mg} / \mathrm{mL}$ & $100 \mathrm{mg} / \mathrm{mL}$ & $10 \mathrm{mg} / \mathrm{mL}$ & $100 \mathrm{mg} / \mathrm{mL}$ & $10 \mathrm{mg} / \mathrm{mL}$ & $100 \mathrm{mg} / \mathrm{mL}$ \\
\hline Spondias pinnata & 11 & 26 & 10 & 0 & 16 & 21 \\
\hline Melia azedarach & 6 & 22 & 12 & 14 & 12 & 22 \\
\hline Psidium guajava & 20 & 35 & 17 & 19 & 17 & 21 \\
\hline Agerantina adenophora & 17.5 & 21 & 13 & 14 & 0 & 0 \\
\hline Bauhinia variegata & 12 & 24 & 0 & 0 & 15 & 21 \\
\hline Achyranthes aspera & 5 & 20 & 17 & 20 & 13 & 13 \\
\hline Eleocarpusan jastifolius & 15 & 26 & 11 & 0 & 0 & 13 \\
\hline Curcuma longa & 11 & 17 & 15 & 17 & 15 & 15 \\
\hline Positive control (Ofloxacin) & \multicolumn{2}{|l|}{20} & \multicolumn{2}{|l|}{35} & \multicolumn{2}{|l|}{38} \\
\hline Negative control & \multicolumn{2}{|l|}{0} & \multicolumn{2}{|l|}{0} & \multicolumn{2}{|c|}{0} \\
\hline
\end{tabular}

ZOI ranged from $0 \mathrm{~mm}$ to $20 \mathrm{~mm}$ against $E$. coli and 19 $\mathrm{mm}$ being ZOI of $P$. guajava at $100 \mathrm{mg} / \mathrm{mL}$ concentration and the standard, ofloxacin $(0.3 \%)$ showed ZOI of 35 $\mathrm{mm}$. Similarly, ZOI ranged from $12 \mathrm{~mm}$ to $22 \mathrm{~mm}$ against $S$. aureus with highest $22 \mathrm{~mm}$ being from $M$. azederach at $100 \mathrm{mg} / \mathrm{mL}$ concentration. The standard ofloxacin showed ZOI of $38 \mathrm{~mm}$ against $S$. typhi. The plant extract of $P$. guajava showed highest ZOI of $35 \mathrm{~mm}$, which was the remarkable antibacterial potential against Salmonella typhi at $100 \mathrm{mg} / \mathrm{mL}$ concentration. The standard, however, showed ZOI of only $20 \mathrm{~mm}$ against this strain.

\section{In-vitro $\alpha$-amylase inhibition activity}

$\alpha$-amylase inhibitory activity of plant extracts was determined from quantitative starch-iodine method. The percentage inhibition of different plant extracts versus concentration and antidiabetic activity in term of $\mathrm{IC}_{50}$ values of different extract are shown below:

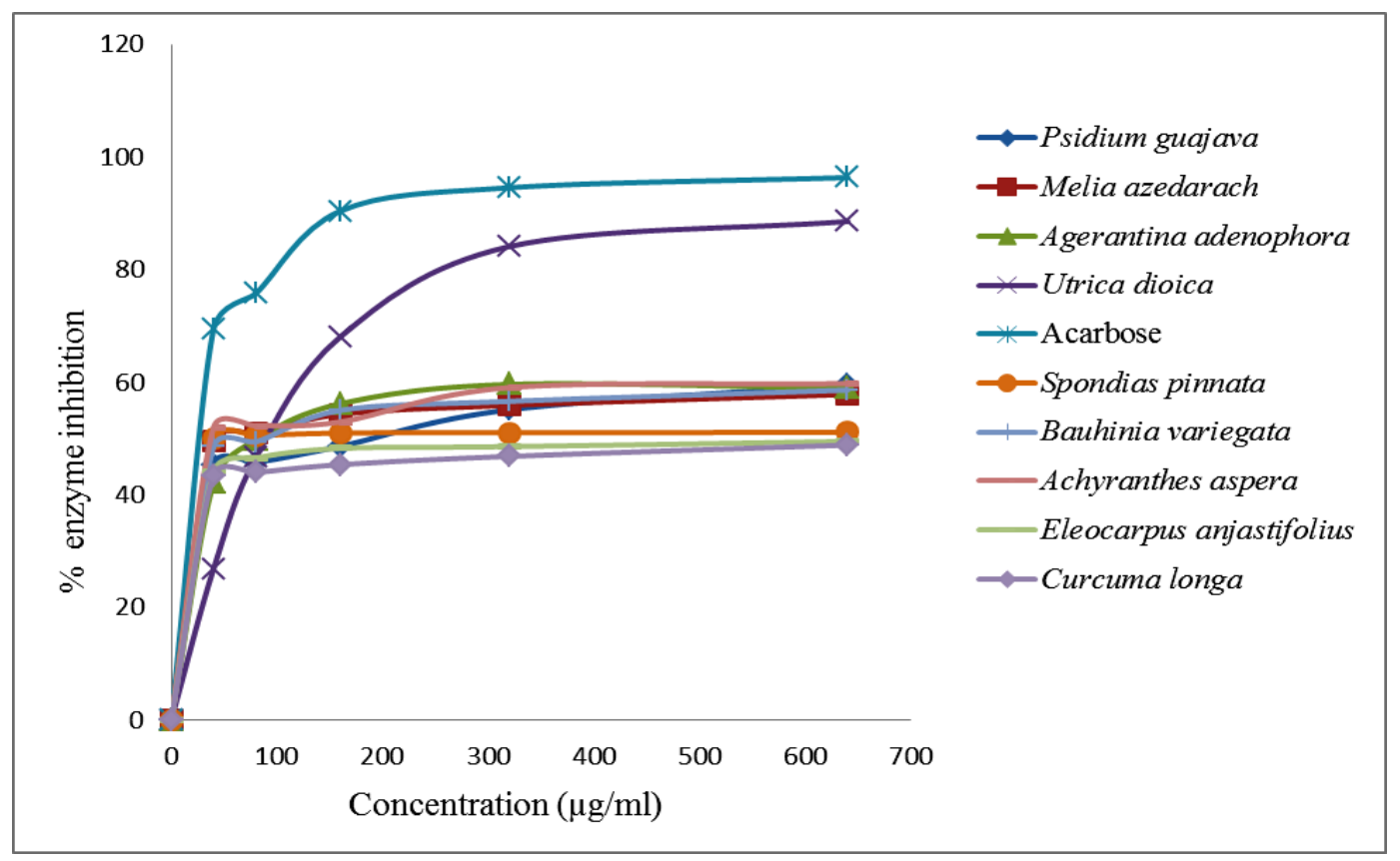

Fig. 1. $\alpha$-amylase inhibition activity with different concentration of plant extracts 
Table 3. $\alpha$-Amylase inhibition activity

\begin{tabular}{ll}
\hline Plant extracts & $\mathbf{I C}_{\mathbf{5 0}}(\boldsymbol{\mu g} / \mathbf{m L})$ \\
\hline Acarbose & 166.01 \\
Spondia spinnata & 412.72 \\
Melia azedarach & 515.91 \\
\hline Psidium guajava & 339.61 \\
Agerantina adenophora & 304.75 \\
Utrica dioica & 186.67 \\
Bauhinia variegata & 309.26 \\
Achyranthes aspera & 284.5 \\
Eleocarpus anjastifolius & 471.74 \\
Curcuma longa & 505.63 \\
\hline
\end{tabular}

The percentage inhibition of Utrica dioica was found to be concentration dependent with a steep rise in percentage inhibition with concentration and its value was $88.56 \pm$ 3.50 at $640 \mu \mathrm{g} / \mathrm{mL}$ concentration. The standard, acarbose displayed percentage inhibition of $90.49 \pm 1.75$ at the same concentration. The plant extracts except Utrica dioica showed the percent inhibition ranging from 40 to 60 with gradual increase in percent inhibition with increase in concentration. Again, the $\mathrm{IC}_{50}$ values of different plants extract along with standard were evaluated and found that the value ranged from $186.67 \mu \mathrm{g} / \mathrm{mL}$ to $515 \mu \mathrm{g} / \mathrm{mL}$. The maximum percent inhibition by Utrica dioica depicted the $\mathrm{IC}_{50}$ value $186.67 \mu \mathrm{g} / \mathrm{mL}$ while standard, acarbose showed $\mathrm{IC}_{50}$ value of $166.01 \mu \mathrm{g} / \mathrm{mL}$. Thus, among the selected medicinal plants, $U$. dioica showed the highest percentage inhibition of $\alpha$-amylase.

\section{Brine shrimp toxicity}

The pure compounds/extracts from the natural source must be examined for its toxicity before it is preceded for translational studies. The extract of different medicinal plants was screened for in vitro cytotoxic activity by brine shrimp lethality test.

The result showed that $\mathrm{LC}_{50}$ of different plant extracts ranged from 62.10 to $1.20 \times 10^{7} \mu \mathrm{g} / \mathrm{mL}$ of Curcuma longa and Achyranthes aspera, respectively. Curcuma longa can be inferred to have very strong toxic effect. Likewise, Agerantina adenophora, Psidium guajava and Melia azedarach revealed a moderate toxicity with 103.77, 109.37 and $383.58 \mu \mathrm{g} / \mathrm{mL}$, respectively. So, these plants can be suggested to be used as therapeutic agents. However, Achyranthes aspera, Bauhinia variegata, Utrica dioica and Spondias pinnata showed very low or insignificant toxicity effect. Plant extract resulting in $\mathrm{LC}_{50}$ less than $1 \mathrm{mg} / \mathrm{mL}$ are considered toxic to the larvae (Muhammad \& Sirat 2013)
Table 4. Toxicity of plant extracts

\begin{tabular}{ll}
\hline Plant extracts & $\mathbf{L C}_{\mathbf{5 0}}(\boldsymbol{\mu g} / \mathbf{m L})$ \\
\hline Spondia spinnata & 146702.59 \\
Melia azedarach & 383.58 \\
Psidium guajava & 109.37 \\
\hline Agerantina adenophora & 103.77 \\
\hline Utrica dioica & 32944.11 \\
Bauhinia variegata & 283486.37 \\
Achyranthes aspera & $1.20 \times 10^{7}$ \\
\hline Eleocarpus anjastifolius & 1391.12 \\
Curcuma longa & 62.10 \\
\hline
\end{tabular}

\section{CONCLUSION}

This study provides some scientific support for the use of traditional medicinal plants in the management of several ailments. P. guajava, M. azedarach and A. aspera can be used as the potential sources for natural antibacterial agent and provides scientific support to the traditional claims of various tribes regarding curative effects. C. longa showed high toxic effect in comparison to plant extracts Melia azedarach, Psidium guajava and Agerantina adenophora with moderate cytotoxic effect. Anti-diabetic assay depicted the wide range of percent inhibition in different plants extracts. However, $U$. dioica was found potent $\alpha$ amylase inhibitor and showed the inhibition near to the standard acarbose. The plant extract with lower $\mathrm{IC}_{50}$ value will be greatly beneficial to reduce the rate of digestion and absorption of carbohydrate and thereby contribute for effective treatment of diabetes by decreasing hyperglycemia. Thus we recommend that further bioassay guided fractionation and isolation approaches are required on the active plant extract to identify the compound responsible for the promising in-vitro anti-diabetic activity.

\section{ACKNOWLEDGEMENTS}

Authors are thankful to Prof. Dr. Mohan Siwakoti and Prof. Dr. Sangeeta Rajbhandari of Central Department of Botany, Tribhuvan University, Kirtipur, Kathmandu for identification of plants and are grateful to the Central Department of Chemistry for laboratory facilities.

\section{REFERENCES}

Arif, T., Sharma, B., Gahlaut, A., Kumar, V. and Dabur, R. 2014. Anti- diabetic agents from medicinal plants: a review. Chemical Biology Letters 1(1): 1-13.

Baral, R.S. 2005. A handbook of medicinal plants in Nepal. 15: 347. 
Biswas, S., Das, J., Raihon, S.Z. and Muhit, A. 2012. Phytochemical investigation with assessment of cytotoxicity and antibacterial activities of the ethanol extract of Elaeocarpusserratus.American Journal of Plant Physiology 7(1): 47-52.

Cavalieri, S.J., Rankin, I.D., Harbeck, R.J. and Sautter, R.L. 2005. Manual of antimicrobial susceptibility testing. American Society for Microbiology.

Chhetri, R.B. and Gauchan, D.P. 2007. Traditional knowledge on fruits pulp processing of Lapsi in Kavrepalanchowk district of Nepal. Indian Journal of Traditional Knowledge 6(1): 46-49.

Giri, D. and Rajbhandari, M. 2018. Phytochemical analysis and constituents of hexane extract of Melastoma malabathricum L. Journal of Institute of Science and Technology 23: 18-25.

Joshi, S. and Bashyal, S. 2018. Study on the chemical constituents and antibacterial activity of essential oil of Acorus calamus L. rhizomes of Rupendehi district (Nepal). Journal of Institute of Science and Technology 23: 57-60.

Kusano, R., Ogawa, S., Matsuo, Y., Yazaki, Y. and Kouno, I. 2011. $\alpha$-amylase and lipase inhibitory activity and structural characterization of acacia bark proanthocyanidins. Journal of Natural Products 74: 119-126.

Lyndy, J. and Jacobus, N. 2014.Cytotoxicity of African medicinal plants against normal animal and human cells. Toxicological Survey of African Medicinal Plants, 181-233.

Meyer, B.N., Ferrigni, N.R., Putnam, J.E. and Nicols, J.L. 1982. Brine shrimp: A convenient general bioassay for active plant constituents. Planta Medica 45(5): 31- 40 .

Muhammad, A., Rahman, M.S., Kabir, A.H., Kabir, S. and Hossain, M.K. 2011. Antibacterial and cytotoxic activiies of Spondiaspinnata (Linn.f.) Kurz fruit extract. Indian Journal of Natural Products and Resources 2(2): 265-267.

Muhammand, A. and Sirat, H.M. 2013. Antimicrobial, antityrosinase and brine shrimp lethality test of Bauhinia rufescensLum (Fabaceae). Journal of Coastal Life Medicine 1(2): 135-140.

Pokhrel, B., Raut, S. and Rijal, S. 2015. Phytochemical screening, antimicrobial and antioxidant activity of Meliaazedarach leaves in methanol solvent. World Journal of Pharmacology \& Pharmaceutical Science 4:1562-1575.

Roa, M., Padyanas, S., Dipin, K.M., Kumar, S., Nayak, B.B. and Varela, M.F. 2018. Antimicrobial compounds of plant origin as efflux pump inhibitors: new avenues for controlling multidrug resistant pathogens. Journal of Antimicrobial Agents 4(1): 159.

Sarah, Q.S., Anny, F.C. and Misbahuddin, M. 2017. Brine shrimp lethality assay. Bangladesh Journal Pharmacology 12: 186-189.

Sathiavelu, A., Sangeetha, S., Archit, R. and Mythili, S. 2013. In vitro anti-diabetic activity of aqueous extract of the medicinal plants Nigella sativa, Eugenia jambolana, Andrographis paniculata and Gymnemasyl vestre. International Journal of Drug Development and Research 5(2): 323-328.

Sharma, K., Adhikari, A., Choudhary, M., Awale, S. and Kalauni, S. 2015a. Bioassay guided isolation of free radical scavenging agent from the bark of Bridelia retusa. Journal of Institute of Science and Technology 20(1): 97-101.

Sharma, K., Kalauni, S. and Awale, S. 2015b. Antioxidant, phytotoxic and antimicrobial activities of methanolic extract of Bauhinia variegata barks. Journal of Institute of Science and Technology 20(2): 37-41.

WHO. 2002. Reducing risks promoting healthy life. The World Health Report, pp. 1-14. 